\title{
Reminder system for health screening in early childhood - an analysis regarding different social circumstances
}

\author{
Simone Weyers ${ }^{*} \mathbb{0}$, Annika Höhmann, Simon Götz and Katharina Kreffter
}

\begin{abstract}
Background: Children with a low socio-economic position (SEP) participate in prevention and health examinations less often. In order to increase participation, reminder systems have been implemented in Germany since 2009. The aim of the study is to investigate whether this implementation is associated with an increased participation in health examination in early childhood for children in disadvantaged social circumstances.

Methods: We used data from the school enrolment examination from 2002 to 2017 from the city of Duesseldorf ( $n=64,883$ children). With a trend analysis we observed health examination over time and we compared rates of children after implementation of the reminder system (2010 or later) to those who were not exposed to the programme (earlier than 2010). Health examination was measured by participation in the last examination before school entry ("U9") documented by paediatricians. Social circumstances included neighbourhood deprivation (very high to very low), migration background (foreign first language vs. German) and family status (one-parent vs. two-parent families). Poisson regression estimated adjusted Prevalence Ratios (PR) with a 95\% confidence interval (Cl) of U9 participation by reminder system exposure, both for the total population and within groups of social circumstances. Based on that, we calculated adjusted participation rates (predictive margins) by reminder system exposure for the different social circumstances.

Results: Participation rates increased slightly, but gradually over time. The probability of U9 participation for children exposed to the reminder system is 1.04-fold (1.03-1.04 Cl) compared to children who were not exposed to it. The association of the reminder system and U9 participation differs according to social circumstances. Adjusted prevalences increased the most in the group of children from very deprived neighbourhoods, ranging from 84.3 to $91.4 \%$ $(\mathrm{PR}=1.07 ; 1.03-1.10 \mathrm{Cl})$; in all language groups; more in children from one-parent families ranging from 82.4 to $88.9 \%$ $(\mathrm{PR}=1.07 ; 1.05-1.09 \mathrm{Cl})$.
\end{abstract}

Conclusion: Our results suggest that reminder systems have a moderate impact on the participation in health examinations in early childhood in the general population. In vulnerable groups, however, they could make a difference. Reminder systems should be combined with further activities of tailored prevention.

Keywords: Child health, Social inequalities, Prevention

*Correspondence: weyerss@uni-duesseldorf.de

Institut für Medizinische Soziologie, Centre for Health and Society,

Medizinische Fakultät, Heinrich-Heine-Universität Düsseldorf, Düsseldorf, Germany

\section{Background}

Children with a low socio-economic position (SEP) have a higher risk of poor general health and health constraints than their peers with a higher SEP $[1,2]$. At the same time they participate less often in prevention and 
health promotion, among which are the nine health examinations "U1 - U9" in early childhood that are provided free of charge in Germany by outpatient paediatricians [3-5].

These "U-examinations" aim to identify health problems in a timely manner and to initiate health promoting measures for the child. To this end, nine examinations are carried out in a given time window from U1 at birth to U9 in the fifth year of live. Each examination has a have specific focus, e.g. physical development, language development or vaccination status. Another purpose of the U-examination is to detect situations of social emergency and child welfare risk. Against the background of several cases of child abuse in Germany in 2006 and 2007, a Federal law was created in order to increase participation in U-examinations. Most German States implemented a mandatory invitation, reminding and reporting system [6]. If a family has not recuperated the missed U-examinations upon further request, a central organisation transfers the case to the local health or youth welfare authorities. These approach the family, where necessary by means of a home visit, inform them about the aim and procedure of the U-examination and offer a subsidiary examination by a public medical officer [6]. In the German State of North Rhine-Westphalia, a reminder system was implemented in 2010, where participation in U5 to U9 was checked and parents were reminded to participate if necessary [7].

Reminder systems for child health promotion have been predominantly used in terms of health screening and immunisation. According to the review of Jacobson Vann et al. [8] including 75 studies reminding people, e.g. by calls, cards or test messages, increases participation in vaccinations, also in children. First experiences in the German Federal States also showed that, after implementation of the Federal law, participation increased, especially from 4 years of age onwards [9]. Also, an evaluation in North Rhine-Westphalia based on administrative data showed that participation in U5 to U9 generally increased [7]. Given the above-mentioned inequalities in child health, it is important to examine if also children with a low socio-economic position benefit from reminder systems. In the North Rhine-Westphalian study a social comparison was made on a district group level with the result that there is an association of unemployment and participation rates in the U-examinations (Ibidem, p. 4). Furthermore, in a survey of paediatricians in the State of Schleswig-Holstein, an increased participation was observed in socially disadvantaged families and those with a migration background [10]. However, social differential analyses of reminder systems in child health based on individual and objective data have been lacking so far. The aim of the study was therefore to investigate if the implementation of a reminder system is associated with an increased participation in health examination in early childhood for children in disadvantaged social circumstances. We did so using administrative data of the city of Duesseldorf.

\section{Methods}

We used anonymised data of the school enrolment examination (SEE) that is mandatory for each child before school entry. It is carried out by public medical officers, paediatricians working in the public health service of the community. The primary aim of this examination is to detect health and developmental disorders that are relevant for school success and to advise parents regarding therapy [11]. Moreover, vaccination status and participation in health examinations and therapies are assessed. The SEE includes families from all social circumstances and, therefore, allows social differential analyses of different aspects of child health $[12,13]$. The present study comprises full samples of 16 SEE cohorts from 2002 to 2017 from the city of Duesseldorf with a total of 73,457 children. With a trend analysis with repeated cross sectional studies we observed health examination over time and we compared health examination rates of children after implementations of the reminder system in North Rhine-Westphalia to those that were not yet exposed to the programme.

Variables were measured as follows: Health examination was operationalised using the example of the U9, the last examination before school entry. U9 participation was taken from the child's "yellow booklet" where paediatricians document all U-examinations. The reminder system programme was approximated by the year 2010 where implementation was fully completed [7]. Since the U9 examination and school enrolment examination are both conducted at 6 years of age, children with SEE in 2010 or later were defined as exposed. Due to data protection, the administrative data does not include regular indicators of a child's socio-economic position such as a parental education, occupation and income. However, three indicators for disadvantaged social circumstances in the context of child health [14-16] were available: (i) neighbourhood deprivation was defined by the sociospatial degree of deprivation for children's residential addresses. Based on indicators such as unemployment and living space per person the local authorities classified 166 social spaces into five neighbourhood types ranging from very high to very low deprivation [17]. This construction of such types is meanwhile common in larger German cities [18] and it recognizes evidencebased markers of economic disadvantage [19]; (ii) migration background was operationalised by the child's first language that was assessed by public medical officers in 
the SEE anamnestic interview. We compared Yugoslav, Turkish, Russian, Moroccan and other first languages to German; (iii) growing up in one-parent-families. Family status was also assessed in the SEE interview and we compared one-parent to two-parent families.

All children who presented the yellow booklet with information on U-examinations were included in the analyses. First, we calculated U9 participation rates for each cohort and according to social circumstances. Then, we used Poisson regression [20] to estimate Prevalence Ratios (PR) with a 95\% confidence interval (CI) of U9 participation by reminder system exposure, both for the total population and within groups of social circumstances (adjusted for age, sex and the other indicators of social circumstances). Based on that we calculated adjusted participation rates (predictive margins [21];) by reminder system exposure for the different social circumstances. Finally, in order to test differences in the increase of participation rates between social groups we calculated multiplicative interaction terms and performed a Wald test (not shown). All analyses were conducted using Stata 14.

\section{Results}

Sixty-four thousand eight hundred eighty-three children were included in the analyses. Overall, $89.3 \%$ of children participated in the U9 examination and $43.4 \%$ were exposed to the reminder system. With $27.0 \%$, more than one fourth of children lived in a (very) deprived neighbourhood, $35.1 \%$ did not speak German as their first language and $12.5 \%$ grew up in a one-parent family (Table 1). The large number of missing values in the latter two variables results from the fact that both were not available for three cohorts (see also Table 2).

Figure 1 shows the U9 participation rates by cohorts. With rates increasing from $86.2 \%$ in 2002 to $92.8 \%$ in 2017 we observed a slight upward trend by $7 \%$ percentage points.

Table 2 displays U9 participation rates according to social circumstances. The percentage difference from 2002 to 2017 within groups of neighbourhood deprivation increases from $2.1 \%$ in the least deprived group to $21.4 \%$ in the most deprived group. Also, an increase in U9 participation is observed not only in children with German as their first language but also, and quite steeper, in children with a foreign first language. Finally, with $12.3 \%$ in one-parent families, the increase is higher when compared with two-parent families with 5.7\%.

For further analyses the cohorts were grouped into those children exposed to the implemented programme and those who were not. Table 3 shows that the probability of U9 participation for children exposed to the reminder system is 1.04-fold (1.03-1.05 CI) compared
Table 1 Sample characteristics

\begin{tabular}{llll}
\hline Variable (missing values) & Categories & n (mean) & \% (SD) \\
\hline Age (366) & & $(5.58)$ & $(0.50)$ \\
Sex (1) & Male & 33,323 & 51.4 \\
& Female & 31,559 & 48.6 \\
U9 participation (0) & No & 6978 & 10.8 \\
& Yes & 57,905 & 89.3 \\
Reminder system (0) & Not exposed & 36,712 & 56.6 \\
Neighbourhood deprivation & Exposed & 28,171 & 43.4 \\
(1.995) & Very low & 5531 & 8.5 \\
& Low & 16,408 & 25.3 \\
& Middle & 23,474 & 36.2 \\
& High & 13,808 & 21.3 \\
First language (13.916) & Very high & 3667 & 5.7 \\
& German & 31,180 & 48.1 \\
& Other & 10,869 & 21.3 \\
& Yugoslav & 1392 & 2.2 \\
& Turkish & 3569 & 5.5 \\
Total & Russian & 1962 & 3.0 \\
& Moroccan & 1995 & 3.1 \\
& Two-parent family & 44,721 & 68.9 \\
& One-parent family & 8089 & 12.5 \\
& & $\mathbf{6 4 , 8 8 3}$ & $\mathbf{1 0 0 . 0 0}$ \\
& & &
\end{tabular}

$N$ Number, SD Standard deviation

to children who were not exposed. This association is adjusted for age, sex and social circumstances. Moreover, the latter are associated with U9 participation: With an $\mathrm{PR}=0.97(0.95-0.99 \mathrm{CI})$ children from very deprived neighbourhoods have a lower probability for U9 participation compared to those from well-off neighbourhoods; children with a foreign first language have a lower probability than their peers with German as their first language; children who have grown up in one-parent families than their peers from two-parent families $(\mathrm{PR}=0.94 ; 0.93-0.95 \mathrm{CI})$.

The following three figures recapitulate that the association of a reminder system and U9 participation differs according to social circumstances. Figure 2 shows that, after programme implementation, the adjusted prevalences of U9 participation increase the most in the group of children from very deprived neighbourhoods, ranging from 84.3 to $91.4 \%$ ( $P R=1.08$; $1.05-1.12 \mathrm{CI}$; results not shown). In the group of children from deprived neighbourhoods the increase from 86.0 to $89.2 \%$ is less steep $(\mathrm{PR}=1.03 ; 1.12-1.05 \mathrm{CI})$. A strong increase from 87.9 to $93.7 \%$ is also observed in the group of children from the least deprived neighbourhoods ( $\mathrm{PR}=1.07 ; 1.05-1.09$ $\mathrm{CI})$. However, group differences are statistically not significant. Results are adjusted for age, sex and the other indicators of social circumstances. 


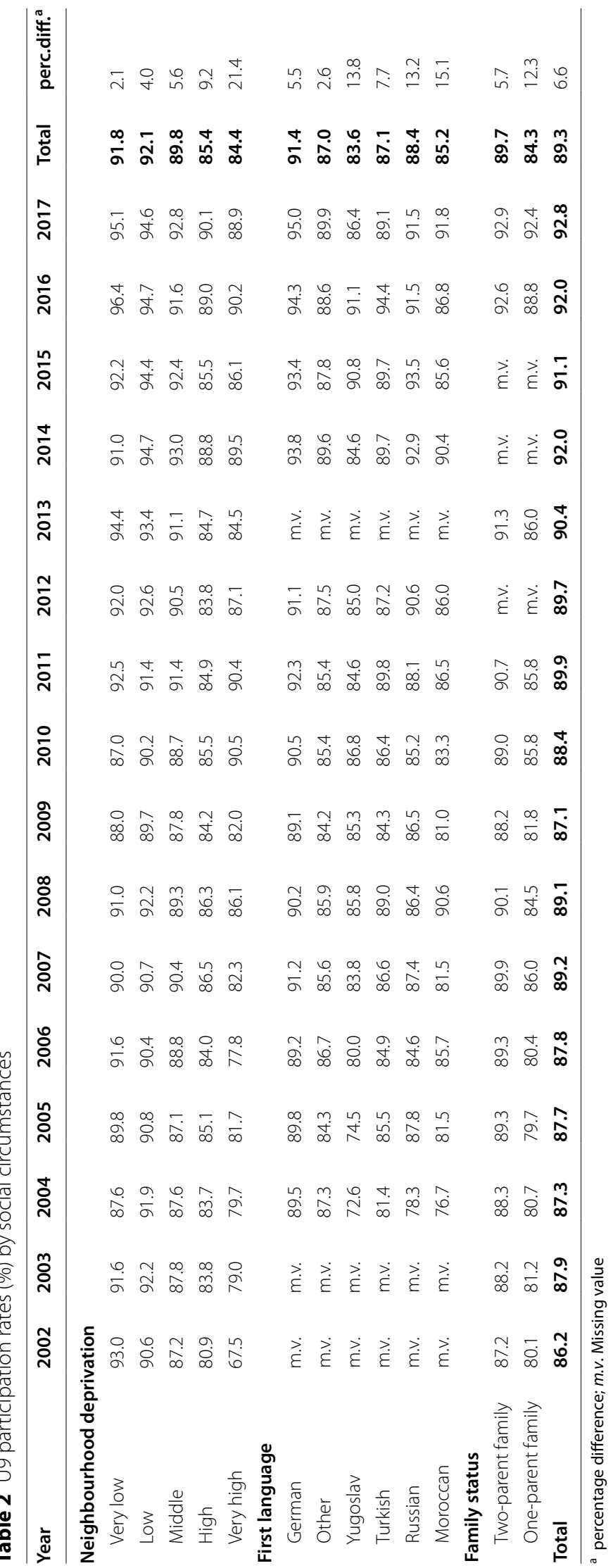




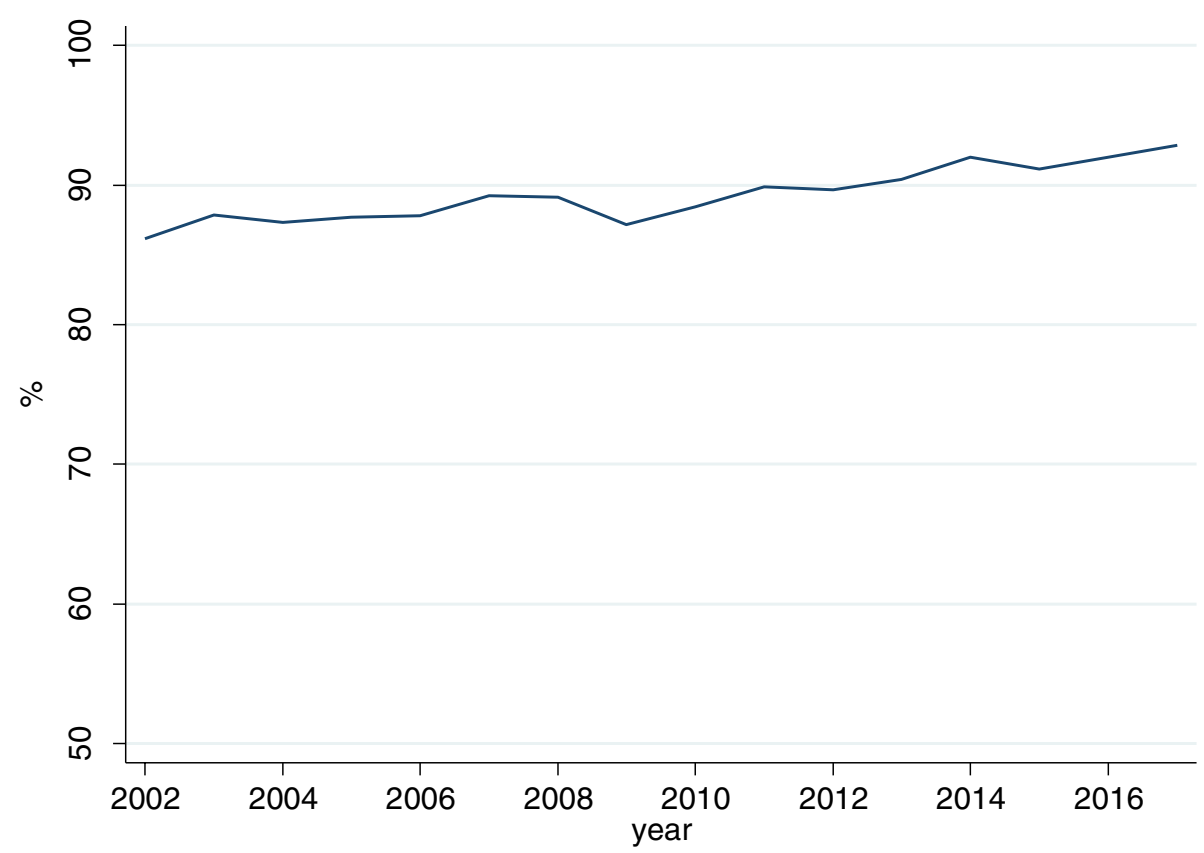

Fig. 1 Participation rates in the total population

Table 3 Prevalence Ratios (PR) with a 95\% Confidence Interval (Cl) for U9 participation

\begin{tabular}{|c|c|c|}
\hline U9 participation & PR & $95 \% \mathrm{Cl}$ \\
\hline No reminder system & Reference & \\
\hline Reminder system & 1.04 & $1.03-1.05$ \\
\hline Neighbourhood deprivation: very low & Reference & \\
\hline Low & 1.00 & $1.00-1.02$ \\
\hline Medium & 1.00 & $0.99-1.01$ \\
\hline High & .97 & $0.96-0.98$ \\
\hline Very high & .97 & $0.95-0.99$ \\
\hline First language: German & Reference & \\
\hline Other & .95 & $0.94-0.96$ \\
\hline Yugoslav & .92 & $0.90-0.95$ \\
\hline Turkish & .96 & $0.95-0.98$ \\
\hline Russian & .96 & $0.94-0.98$ \\
\hline Moroccan & .93 & $0.91-0.95$ \\
\hline Family status: Two-parent family & Reference & \\
\hline One-parent family & .94 & $0.93-0.95$ \\
\hline
\end{tabular}

Significant results in bold letters

Stratified by first language, an increase of U9 participation is observed in all language groups (Fig. 3). It ranges from $89.893 .4 \%$ in children with German as their first language ( $\mathrm{PR}=1.04 ; 1.03-1.05 \mathrm{CI}$; results not shown); from 82.5 to $87.6 \%(\mathrm{PR}=1.07 ; 1.01-1.14 \mathrm{CI})$ in children with Yugoslav as their first language; from 85.9 to $91.2 \%$ $(\mathrm{PR}=1.06 ; 1.03-1.09 \mathrm{CI})$ in children with Turkish as their first language; from 85.6 to $90.8 \%(\mathrm{PR}=1.06$; 1.02 $1.10 \mathrm{CI})$ in children with Russian as their first language and from 83.2 to $88.5 \%(\mathrm{PR}=1.07 ; 1.02-1.11 \mathrm{CI})$ in children with Moroccan as their first language. Again, group differences are statistically not significant.

Finally, the increase of U9 participation differs by family status (Fig. 4). While adjusted prevalences increase from 89.2 to $92.3 \%(\mathrm{PR}=1.04 ; 1.03-1.04 \mathrm{CI})$ in children who have grown up in two-parent families, it increases from 82.4 to $89.0 \%(\mathrm{PR}=1.08 ; 1.06-1.10 \mathrm{CI})$ in children from one-parent families. In this case, group differences are statistically significant.

\section{Discussion}

The aim of the study was to investigate if the implementation of a reminder system is associated with an increased participation in health examination in early childhood for children in disadvantaged social circumstances. Overall, participation rates have increased slightly, but gradually over time. The increase of $86.2 \%$ in 2002 to $92.8 \%$ in 2017 is less than that reported in other studies. In the German Health Interview and Examination Survey for Children and Adolescents ("KiGGS") full participation in the U-examinations has increased from $81.6 \%$ in the baseline study (2003-2006) [22] to $97.2 \%$ in wave 2 (2014-2017) [23]. Also, we did not observe a distinct increase after 2010 in our data as we would have expected after full implementation of the reminder system. It is argued that administrative 


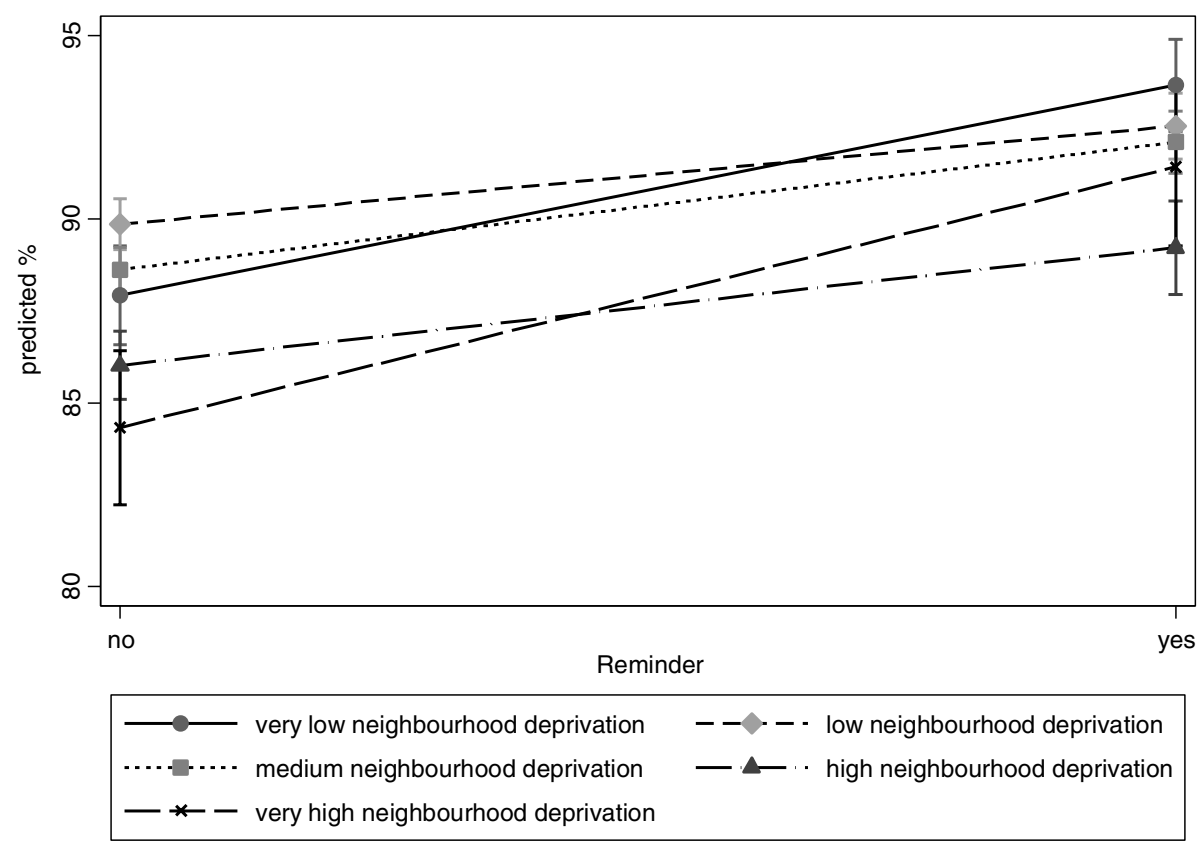

Fig. 2 Adjusted prevalences of U9 participation by neighbourhood deprivation

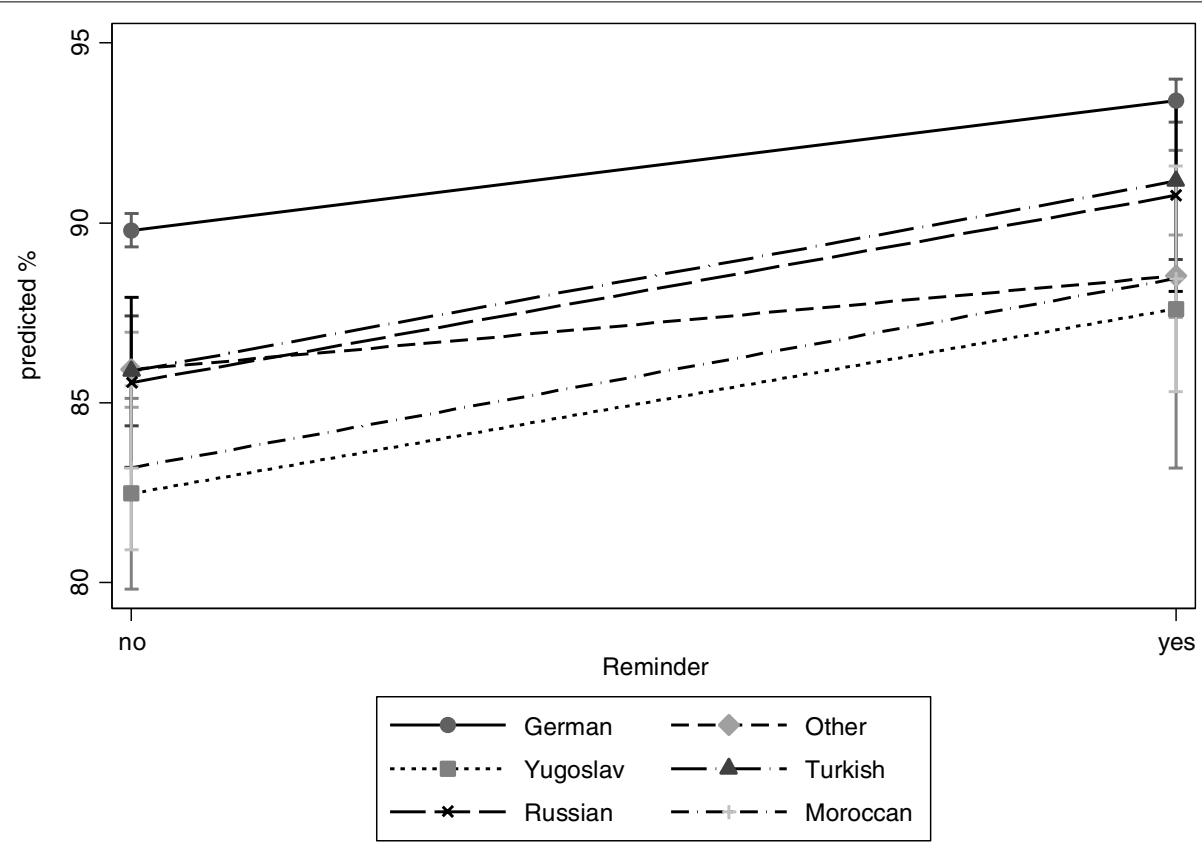

Fig. 3 Adjusted prevalences of U9 participation by migration background (first language)

procedures are optimised step by step [7]. Another explanation for the gradual increase even before programme implementation could be the range of existing community activities: Health insurance companies and authorities are important players in the community system, which transfer families to existing prevention programmes. One health insurance company reported upon request that they had been sending out information brochures since 1996 and personalised letters since 2006. The youth welfare authorities have been visiting 


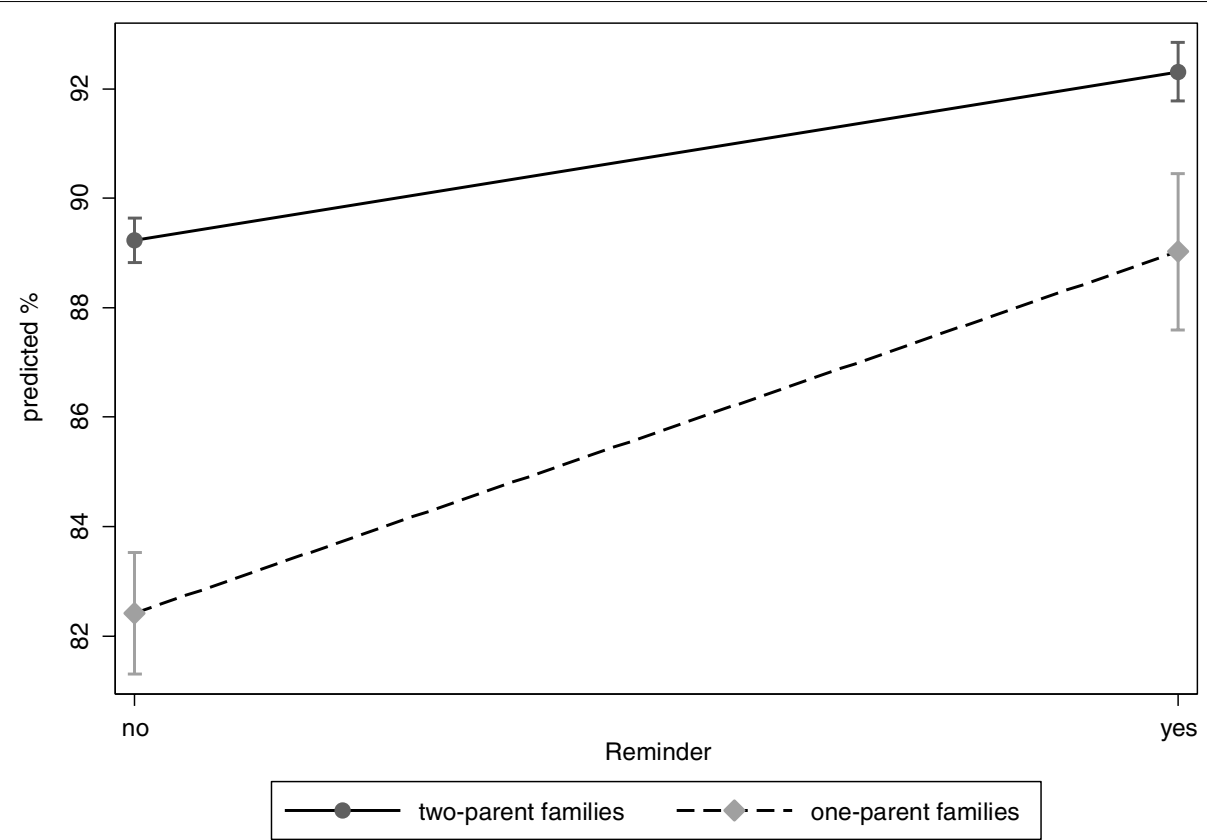

Fig. 4 Adjusted prevalences of U9 participation by family status

all parents of a first born child since 2009 in order to inform them about child development and prevention programmes [24].

In the frame of the social-differential analysis we found several effects: First, the steepest increase was observed in children from very deprived neighbourhoods. This could be explained by the fact that the baseline value was especially low in this group. Also, the reminder system was accompanied by an intensified prevention in Duesseldorf neighbourhoods with special needs since 2012. In the frame of a North Rhine-Westphalian State programme ("No child left behind" [25]) local prevention managers had been implemented in neighbourhoods with special needs. These managers were in close contact with families and transferred them to existing prevention offers. Second, an increase of participation rates was observed for all language groups. It is widely acknowledged that language barriers, unfamiliarity with the health care system and gaps in health literacy impair the accessibility of health services for migrants [26]. Third, a strong increase in participation was observed for children who grow up in one-parent families. There is some evidence that single parents have an increased risk of non-participation in preventive child health examinations $[27,28]$ and incomplete immunisation schedules $[29,30]$. One hypothesis is the time limit of single parents $[28,30]$ and the increase after implementation of the reminder system could be explained by the fact that the examination was simply forgotten.

\section{Limitations}

A central limitation is the operationalisation of the reminder system by implementation year. The reminder was only sent in case of a missed U-examination. If and how families were actually reached could not be assessed by individual data. Furthermore, we could not quantify, which additional factors might have contributed to the increase in participation rates. The concept of the North Rhine-Westphalian reminder system did not foresee direct communication with the target groups, but rather the programme was disseminated by professional associations and communities [7]. Accordingly, additional local measures were necessary that we could not account for.

A strength of the study is that it is based on a large sample. Three different indicators of social circumstances and the U9 participation were objectively measured on an individual level and do not have a substantial bias. This is especially important in the context of a social-differential analysis since the recall bias varies according to sociodemographic factors [4]. Also, due to its naturalistic design, the study's external validity can be rated as rather high. Replication studies in other German cities should examine whether the association of reminder systems and prevention participation remains under different local circumstances. 


\section{Conclusions}

Taken together, our results suggest that reminder systems have a moderate impact on participation in health examination in early childhood. There is some evidence how population groups can be reached by reminder systems: The combination of different communication channels such as a phone call and a letter have proved to be effective in order to promote vaccination in small children $[23,31]$ and in children with chronic disease [32, 33]. With the spread of mobile phones in hard-to-reach population groups the short message service (SMS) has become important. Thereby, SMS with health relevant information [34] and with interactive components [35] were effective in promoting flu-vaccination in children. In order to recruit urban young populations, a stepwise intervention with a phone call, letter and, if unsuccessful, a home visit was promising [36].

Furthermore, our results give the impression that reminder systems should be combined with further activities of tailored prevention in order to have an impact in socially disadvantaged children. In terms of the three different indicators, the following conclusions can be drawn: With regard to neighbourhood deprivation, it should be noted that many German communities have developed socio-spatial classifications based on data such as living space per inhabitant, nationality of inhabitants or number of households on benefits [18]. With this classification, youth welfare interventions can be prioritised to children who grow up in very deprived neighbourhoods. On the other side, children who grow up in (only) deprived neighbourhoods, might "fall through the cracks". With $n=13,808$ children in deprived neighbourhoods in our sample, this missed chance has concerned a large group and, in the future, further selection criteria should be considered in order to focus on preventive behaviour in vulnerable groups. Regarding migration background with language and knowledge barriers towards the health services, it seems that a reminder system insistently calling attention to a given examination has the potential to increase participation. On the other hand, these language and knowledge barriers could be overcome beforehand. Health systems should provide migrants with information in their language. Also, they should aim to improve the health literacy of migrant families by means of targeted health promotion interventions that take into account the different ways in which people perceive and experience health problems [26, 37]. Accordingly, authoritative and costly recall systems could become redundant to a certain extent.

This is particularly important. Preventive measures adopted by governments might sometimes seem necessary and justified. However, they always present ethical and human rights controversies - even if they are effective [38]. The government is sworn to neutrality with regard to the life styles of its citizens [39]. The German constitutional law foresees that "child care and education are the natural right of parents" (Art. 6 para. 2 GG [40];). Despite the social inequalities in child health and prevention mentioned above, governmental strategies have to be weighed up against cutting these rights. One could argue that in our case the informational home visit with the offer of a subsidiary health examination is a good compromise.

\section{Recommendations}

Based on our results and the available evidence, we recommend that reminder systems combine different communication channels and that they are complemented with further activities of tailored prevention such as home visits or culturally-sensitive information for as many vulnerable persons as possible.

\section{Abbreviations}

SEP: Socio-economic position; SEE: School enrolment examination; PR: Prevalence Ratios; Cl: Confidence interval; N: Number; SD: Standard deviation; m.v.: Missing value.

\section{Acknowledgements}

We would like to thank Zsuzsa Gosztonyi for co-developing the study design.

\section{Authors' contributions}

Data analysis was performed by SW, SG and AH. The first draft of the manuscript was written by SW and KK and all authors commented on previous versions of the manuscript. All authors read and approved the final manuscript.

\section{Funding}

The authors declare that they did not receive funding for this study. Open Access funding enabled and organized by Projekt DEAL.

Availability of data and materials

The SEE dates analysed during the current study are not publicly available because the data owner is the city of Duesseldorf.

\section{Declarations}

Ethics approval and consent to participate

Participation in the school enrolment examination is mandatory. Health authorities of the city of Duesseldorf gave permission to access the anonymised raw data. Data analysis was approved by the ethics committee of the Duesseldorf Medical Faculty (study nr. 2019-508).

\section{Consent for publication}

Not applicable.

\section{Competing interests}

The authors declare that they have no competing interest.

Received: 30 May 2021 Accepted: 27 September 2021

Published online: 07 October 2021

\section{References}

1. Inchley J, Currie D, Young T. Editors. Growing up unequal: gender and socioeconomic differences in young people's health and well-being; health behaviour in school-aged children (HBSC) study: international 
report from the 2013/2014 survey. Copenhagen: World Health Organization, Regional Office for Europe; 2016.

2. Kuntz B, Rattay P, Poethko-Müller C, Thamm R, Hölling H, Lampert T. Soziale Unterschiede im Gesundheitszustand von Kindern und Jugendlichen in Deutschland - Querschnittergebnisse aus KiGGS Welle 2. J Health Monitor. 2018:19-36. https://doi.org/10.17886/RKI-GBE-2018-076.

3. Rosenkötter N, van Dongen MCJM, Hellmeier W, Simon K, Dagnelie PC. The influence of migratory background and parental education on health care utilisation of children. Eur J Pediatr. 2012;171:1533-40. https://doi. org/10.1007/s00431-012-1774-9.

4. Rattay P, Starker A, Domanska O, Butschalowsky H, Kamtsiuris P. Trends in der Inanspruchnahme ambulant-ärztlicher Leistungen im Kindes- und Jugendalter. Ergebnisse der KiGGS-Studie - Vergleich von Basiserhebung und erster Folgebefragung (KiGGS Welle 1). Palliativmedizin. 2014 https://doi.org/10.1055/s-0034-1374432

5. Hase J, Hartmann T, Oppermann H, Wahl G. Inanspruchnahme von Früherkennungsuntersuchungen bei Kindern aus Sachsen-Anhalt zum Zeitpunkt der Schuleingangsuntersuchung. [Participation in Preventive Medical Examinations for Children in Saxony-Anhalt (Germany) at the Time of School Entry Medical Examination]. Gesundheitswesen. 2016;78:e6-13. https://doi.org/10.1055/s-0034-1390440.

6. Bundestag D. Früherkennungsuntersuchungen für Kinder in Deutschland - Leistungsangebote der Gesetzlichen Krankenversicherung und landesrechtliche Regelungen zur Steigerung ihrer Inanspruchnahme; 2009

7. Institut für Sozialarbeit und Sozialpädagogik e. V Köhler L, Dittmann J, Sthamer E. Evaluation der Aktion Gesunde Kindheit: Abschlussbericht. Hg. v. Institut für Sozialarbeit und Sozialpädagogik e. V. Frankfurt am Main; 2011

8. Jacobson Vann JC, Jacobson RM, Coyne-Beasley T, Asafu-Adjei JK, Szilagyi PG. Patient reminder and recall interventions to improve immunization rates. Cochrane Database Syst Rev. 2018;1:CD003941. https://doi.org/10. 1002/14651858.CD003941.pub3.

9. Thaiss H, Klein R, Schumann EC, Ellsässer G, Breitkopf H, Reinecke H, et al. Früherkennungsuntersuchungen als Instrument im Kinderschutz. Erste Erfahrungen der Länder bei der Implementation appellativer Verfahren. [Child health check-ups as an instrument in child welfare. First results of compulsory check-up systems in German federal states]. Bundesgesundheitsbl. 2010;53:1029-47. https://doi.org/10.1007/s00103-010-1134-8.

10. BVKJ-SH und Kassenärztliche Vereinigung Schleswig-Holstein. In: Thaiss $\mathrm{H}_{\text {, }}$ Klein R, Schumann EC, Ellsäßer G, Breitkopf H, Reinecke H et al. Früherkennungsuntersuchungen als Instrument im Kinderschutz. Bundesgesundheitsblatt - Gesundheitsforschung - Gesundheitsschutz. 2010:1029-47. https://doi.org/10.1007/s00103-010-1134-8.

11. Bundestag D. Ärztliche Einschulungsuntersuchungen - Rechtslage in den Bundesländern.: Reg.-Nr.:WFIX-153/05; 2006.

12. Weyers S, Wahl S, Dragano N, Müller-Thur K. Ist der Datenschatz schon gehoben?: Eine Übersichtsarbeit zur Nutzung der Schuleingangsuntersuchung für die Gesundheitswissenschaften. Prävention und Gesundheitsförderung. 2018:261-8. https://doi.org/10.1007/s11553-018-0641-6.

13. Wahl S, Kreffter K, Frölich S, Müller-Thur K, Dragano N, Göbels K, et al. Die Schuleingangsuntersuchung als Türöffner für die gesundheitswissenschaftliche Forschung?: Eine Analyse zur Studienteilnahme "schwer erreichbarer" Bevölkerungsgruppen. Is the school entrance examination a door opener for health sciences research? : Analyzing study participation of hard-to-reach groups. Bundesgesundheitsblatt Gesundheitsforschung Gesundheitsschutz. 2018;61:1236-41. https://doi.org/10.1007/ s00103-018-2808-x.

14. Klein J, O von dem K. Inequalities in health care utilization among migrants and non-migrants in Germany: a systematic review. Int J Equity Health. 2018;17:160. https://doi.org/10.1186/s12939-018-0876-z.

15. Amato PR. The impact of family formation change on the cognitive, social, and emotional well-being of the next generation. Futur Child. 2005;15:75-96. https://doi.org/10.1353/foc.2005.0012.

16. Pearce A, Dundas R, Whitehead M, Taylor-Robinson D. Pathways to inequalities in child health. Arch Dis Child. 2019;104:998-1003. https:// doi.org/10.1136/archdischild-2018-314808

17. Golschinski M. Sozialräumliche Gliederung: Fortschreibung. 2017. Online https://www.duesseldorf.de/fileadmin/Amt13/presseanhang/Sozialraeu mliche-Gliederung-Fortschreibung2017.pdf. Accessed 4 Oct 2021.
18. Bartling L, Reher A-K. Konstrukt Sozialraum: Kleinräumigkeit nutzen und analysieren: Eine Arbeitshilfe für Kommunen und Träger; 2019.

19. Messer LC, Laraia BA, Kaufman JS, Eyster J, Holzman C, Culhane J, et al. The development of a standardized neighborhood deprivation index. J Urban Health. 2006;83:1041-62. https://doi.org/10.1007/s11524-006-9094-x.

20. Barros AJD, Hirakata VN. Alternatives for logistic regression in cross-sectional studies: an empirical comparison of models that directly estimate the prevalence ratio. BMC Med Res Methodol. 2003;3:21.

21. Williams R. Using the margins command to estimate and interpret adjusted predictions and marginal effects. Stata J. 2012;12:308-31. https://doi.org/10.1177/1536867X1201200209.

22. Hempel U, Bergmann E, Erhart M, Hölling H, Kahl H, Kamtsiuris P, et al. Erste Ergebnisse der KiGGS-Studie zur Gesundheit von Kindern und Jugendlichen in Deutschland. Berlin: Robert-Koch-Inst; 2006.

23. Schmidtke C, Kuntz B, Starker A, Lampert T. Inanspruchnahme der Früherkennungsuntersuchungen für Kinder in Deutschland - Querschnittergebnisse aus KiGGS Welle 2; 2018.

24. Frese D, Günther C. Willkommensbesuche für Neugeborene: Konzepte, Erfahrungen und Nutzen. Münster, New York, NY, München, Berlin: Waxmann; 2013.

25. Strohmeier KP, Gehne D, Bogumil J, Micosatt G, von Görtz R. Kein Kind zurücklassen! Kommunen in NRW beugen vor: Die Wirkungsweise kommunaler Prävention: Zusammenfassender Ergebnisbericht der wissenschaftlichen Begleitforschung; 2016.

26. Rechel B, Mladovsky P, Ingleby D, Mackenbach JP, McKee M. Migration and health in an increasingly diverse Europe. Lancet. 2013;381:1235-45. https://doi.org/10.1016/S0140-6736(12)62086-8.

27. Freed GL, Clark SJ, Pathman DE, Schectman R. Influences on the receipt of well-child visits in the first two years of life. Pediatrics. 1999;103:864-9.

28. Søndergaard G, Biering-Sørensen S, Michelsen SI, Schnor O, Andersen A-MN. Non-participation in preventive child health examinations at the general practitioner in Denmark: a register-based study. Scand J Prim Health Care. 2008:26:5-11. https://doi.org/10.1080/02813430801940877.

29. Luman ET, McCauley MM, Shefer A, Chu SY. Maternal characteristics associated with vaccination of young children. Pediatrics. 2003;111:1215-8.

30. Kacenelenbogen N, Dramaix-Wilmet M, Schetgen M, Roland M. Parental separation and behaviours that influence the health of infants aged 7-11 months: a cross-sectional study. BMJ Open. 2014;4:e005183. https://doi. org/10.1136/bmjopen-2014-005183.

31. Williams N, Woodward H, Majeed A, Saxena S. Primary care strategies to improve childhood immunisation uptake in developed countries: systematic review. JRSM Short Rep. 2011;2:81. https://doi.org/10.1258/ shorts.2011.011112

32. Esposito S, Pelucchi C, Tel F, Chiarelli G, Sabatini C, Semino M, et al. Factors conditioning effectiveness of a reminder/recall system to improve influenza vaccination in asthmatic children. Vaccine. 2009;27:633-5. https:// doi.org/10.1016/j.vaccine.2008.11.043.

33. Cecinati V, Esposito S, Scicchitano B, Delvecchio GC, Amato D, Pelucchi C, et al. Effectiveness of recall systems for improving influenza vaccination coverage in children with oncohematological malignancies. Hum Vaccin. 2010;6:194-7. https://doi.org/10.4161/hv.6.2.10253.

34. Stockwell MS, Hofstetter AM, DuRivage N, Barrett A, Fernandez N, Vargas $C Y$, et al. Text message reminders for second dose of influenza vaccine: a randomized controlled trial. Pediatrics. 2015;135:e83-91. https://doi.org/ 10.1542/peds.2014-2475

35. Hofstetter AM, Vargas CY, Camargo S, Holleran S, Vawdrey DK, Kharbanda EO, et al. Impacting delayed pediatric influenza vaccination: a randomized controlled trial of text message reminders. Am J Prev Med. 2015;48:392-401. https://doi.org/10.1016/j.amepre.2014.10.023.

36. Szilagyi PG, Humiston SG, Gallivan S, Albertin C, Sandler M, Blumkin A. Effectiveness of a citywide patient immunization navigator program on improving adolescent immunizations and preventive care visit rates. Arch Pediatr Adolesc Med. 2011;165:547-53. https://doi.org/10.1001/archp ediatrics.2011.73.

37. Betsch C, Böhm R, Airhihenbuwa CO, Butler R, Chapman GB, Haase N, et al. Improving medical decision making and health promotion through culture-sensitive health communication: an agenda for science and practice. Med Decis Mak. 2016;36:811-33. https://doi.org/10.1177/02729 $89 \times 15600434$.

38. Hafen M. Ethik in Prävention und Gesundheitsförderung. Präv Gesundheitsf. 2013;8:284-8. https://doi.org/10.1007/s11553-013-0407-0. 
39. Huster S. Gesundheitsförderung durch Wirtschaftsregulierung?: Juristische und ethische Aspekte. In: Fangerau H, Kessler S, Wiesing U, editors. Präventionsentscheidungen: Zur Geschichte und Ethik der Gesundheitsvorsorge im 21. Jahrhundert. Stuttgart-Bad Cannstatt: frommannholzboog; 2017. p. 77-91.

40. Bundesministerium der Justiz und für Verbraucherschutz. Grundgesetz für die Bundesrepublik Deutschland in der im Bundesgesetzblatt Teil III, Gliederungsnummer 100-1, veröffentlichten bereinigten Fassung, das zuletzt durch Artikel 1 u. 2 Satz 2 des Gesetzes vom 29. September 2020 (BGBI. I S. 2048) geändert worden ist: GG; 2021. Online https://www.geset ze-iminternet.de/gg/BJNR000010949.html. Accessed 9 Mar 2021.

\section{Publisher's Note}

Springer Nature remains neutral with regard to jurisdictional claims in published maps and institutional affiliations.
Ready to submit your research? Choose BMC and benefit from:

- fast, convenient online submission

- thorough peer review by experienced researchers in your field

- rapid publication on acceptance

- support for research data, including large and complex data types

- gold Open Access which fosters wider collaboration and increased citations

- maximum visibility for your research: over $100 \mathrm{M}$ website views per year

At BMC, research is always in progress.

Learn more biomedcentral.com/submissions 